\title{
EXPERIMENTAL INVESTIGATION OF PULSE STERILIZATION OF PATHOGENS
}

\author{
Volodymyr Chumakov ${ }^{1 *}$, Mykhailo Ostryzhnyi ${ }^{1}$, Oksana Kharchenko ${ }^{1}$, Nataliya Rybalchenko ${ }^{2}$, \\ Vasiliy Muraveinyk ${ }^{3}$, and Aleksandr Tarasevich ${ }^{3}$ \\ ${ }^{1}$ Kharkiv National University of Radioelectronics, Kharkiv, Ukraine \\ ${ }^{2}$ Danylo Zabolotny Institute of Microbiology and Virology of the National Academy of \\ Science of Ukraine, Kyiv, Ukraine \\ ${ }^{3}$ Limited Liability Company «Triix», Chernihiv, Ukraine
}

Corresponding author: Volodymyr Chumakov, Prof., Dr. of Technical Science, Department of Design and Operation of Electronic Devices, Kharkiv National University of Radio Electronics, 14 ave. Nauky, 61166, Kharkiv, Ukraine, Tel: +380-95-10-15-662, Email: mega1tools@gmail.com

Abstract. The results of experimental investigations of the effect of high-intensity pulsed $U V$ radiation on reference strains of opportunistic pathogens $S$, aureus and $E$. coli are presented. The modified pulse UV sterilizer MПK-300-3 based on an end-face plasma accelerator was used as a radiation source, which provides a power pulsed discharge in an open atmosphere. The high efficiency of inactivation of the pathogens was provided within a short period of time. The possibility of providing urgent 100\% sterilization of a pathogens has been shown. The prospects for the application of pulse sterilization technology to combat pathogens are considered.

\section{INTRODUCTION}

Research on the mechanism and effectiveness of pulsed UV sterilization is ongoing. As a matter of fact, they did not stop, having started almost 30 years ago [1-5]. Successful tests of the technology of pulse sterilization of viral infection opened the prospect for further research on the effect of UV radiation on microorganisms [6]. The results of all the studies carried out show that the high efficiency of pulse sterilization is provided, first of all, by the high power of UV radiation, which is generated in the pulsed mode. At the same time, generators of optical radiation based on magnetoplasmatic compressor (MPC) are the most powerful emitting devices. The purpose of these studies was to show the high efficiency of incoherent pulsed UV-radiation generated during the discharge of an endface coaxial MPC to pathogens and to experimentally confirm the possibility of monopulse sterilization.

\section{MATERIALS AND METHODS}

Studies were performed on reference strains of opportunistic pathogens Staphylococcus aureus UCM B-904 (ATCC 25923), Escherichia coli UCM B906 (ATCC 25922), obtained from the Ukrainian collection of microorganisms (UCM, Institute of Microbiology and Virology of NAS of Ukraine) [7].

To determine the sensitivity of microorganisms to UV-radiation, a test culture of bacteria was incubated for 24 hours at $37^{\circ} \mathrm{C}$ on solid medium LB (Luria-Bertoni). Daily agar cultures were washed with sterile saline, diluted with 
a suspension according to the McFarland 1.0 turbidity standard, followed by dilution to $1 \times 10^{6} \mathrm{CFU}$ (colony-forming units)/ml, $1 \times 10^{4} \mathrm{CFU} / \mathrm{ml}, 1 \times 10^{3}$ $\mathrm{CFU} / \mathrm{ml}$ [8]. Volume $0.1 \mathrm{ml}$ bacterial suspension of the appropriate concentration was inoculated by the lawn on Mueller-Hinton agar plates. Source of UV-radiation was placed so that the device was directed downward and placed at a height of $h=30 \mathrm{~cm}$ from the surface of the laboratory table (Fig. 1). On the table under the ultraviolet sterilizer in the operation area the opened Petri cups inoculated with a certain concentration of bacterial suspension were placed, and a single dose of radiation (1 pulse) was exposed. Next, the irradiated cups were closed and set aside, and in their place the next series of inoculated cups were placed and two exposures of radiation ( 2 pulses) were given. The same principle was used to irradiate 5 and 10 pulses. Petri cups not irradiated with an UV-radiation served as a control. The experiment used three replicates of inoculated cups with different concentrations of bacterial suspension. Irradiated and control cups were incubated in a thermostat at $37^{\circ} \mathrm{C}$ for 24 hours.

The dishes inoculated with cultures in different concentrations were divided into 3 groups, each of which was irradiated with a certain dose of UV radiation. The dose load on a group of cups was set by the number of pulsed exposures

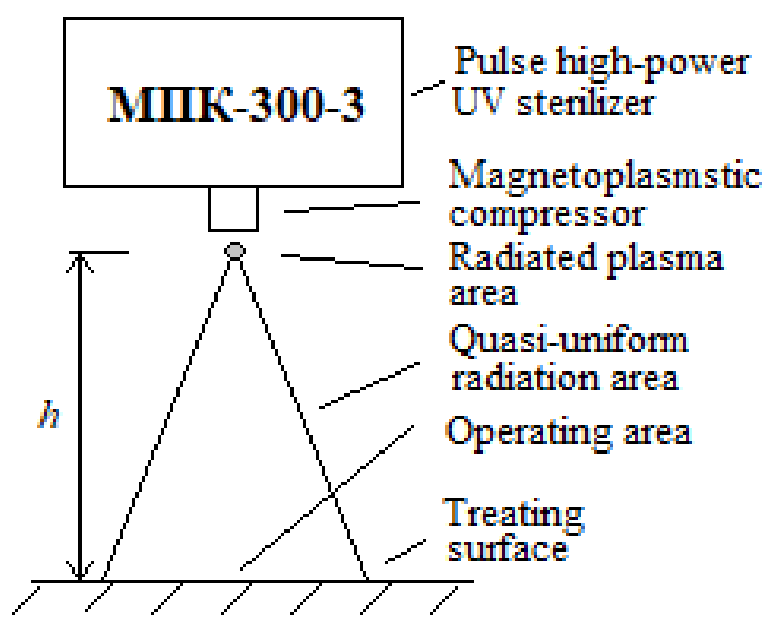

Fig. 1. Experimental investigation scheme

When calculating the results, the number of viable cells was determined, the number of colonies grown on the plates was counted, the cell titer and the survival of irradiated cells as a percentage of control were determined.

A modified MPK-300-3 sterilizer was used as a source of pulsed UV radiation [6]. The circuitry implementation of the main units of the device, the control circuit and the appearance have undergoned modernization. The switching elements of the charging-discharge circuit of the electric energy storage have been completely renewed and strengthened. Fig. 2 represents an updated equipment. Currently, the device provides operation both in the mode of generating single pulses and in the mode of forming a pulse train of a given 
duration. The use of modern element base has made it possible to increase the stability of the parameters of radiation pulses.

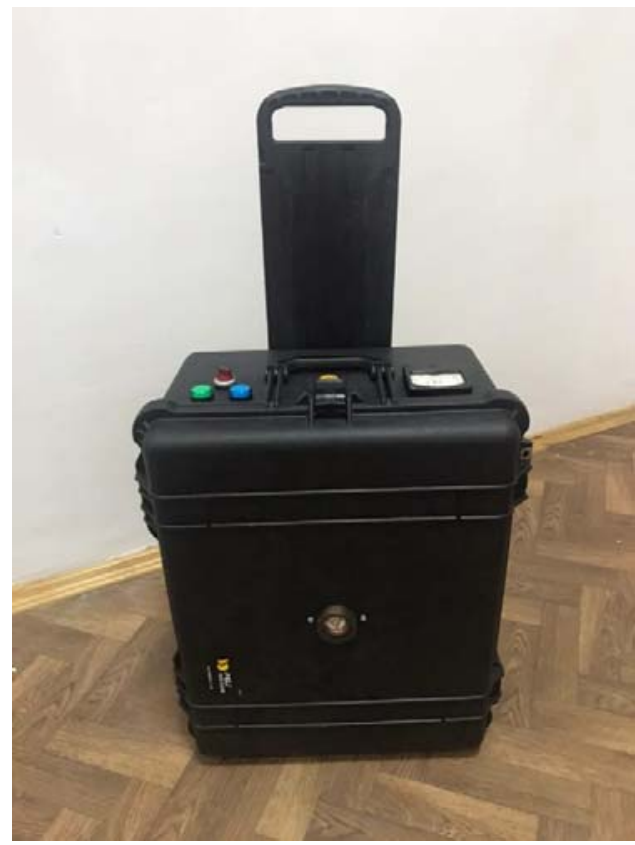

a)

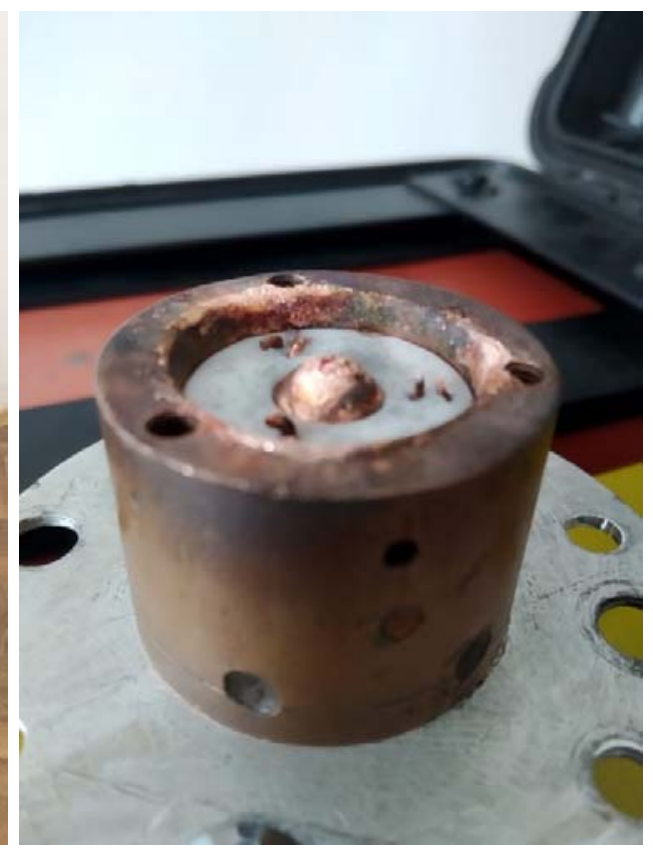

b)

Fig. 2. Updated model of the high-power pulse UV sterilizer МПК-300-3 (a), radiator unit (MPC) (b)

\section{RESULTS AND DISCUSSION}

The results of the study of the effectiveness of the pulsed UV-radiation against reference strains of opportunistic pathogens $\underline{S \text {. aureus }}$ and E.coli are presented in Tab. 1, 2 and Fig. 3-8.

Table 1. The effectiveness of pulsed UV-radiation against $S$. Aureus

\begin{tabular}{|c|c|c|c|c|}
\hline Test-culture & $\begin{array}{l}\text { Initial bacterial suspension } \\
\text { concentration, control, } \\
\text { CFU/ml }\end{array}$ & $\begin{array}{l}\text { Number of } \\
\text { pulse } \\
\text { exposition }\end{array}$ & $\begin{array}{l}\text { Resulted number of } \\
\text { growth colonies }\end{array}$ & $\begin{array}{l}\text { Efficiency } \\
\%\end{array}$ \\
\hline \multirow{12}{*}{ S. aureus } & \multirow[t]{4}{*}{$10^{6}$} & 1 & 272 & 99,97 \\
\hline & & 2 & 124 & 99,98 \\
\hline & & 5 & 16 & 99,99 \\
\hline & & 10 & 0 & 100 \\
\hline & \multirow[t]{4}{*}{$10^{4}$} & 1 & 35 & 99,65 \\
\hline & & 2 & 20 & 99,80 \\
\hline & & 5 & 2 & 99,98 \\
\hline & & 10 & 0 & 100 \\
\hline & \multirow[t]{4}{*}{$10^{3}$} & 1 & 1 & 99,90 \\
\hline & & 2 & 1 & 99,90 \\
\hline & & 5 & 0 & 100 \\
\hline & & 10 & 0 & 100 \\
\hline
\end{tabular}

As can be seen from the results of the research, the ultraviolet sterilizer MПK-300-3 showed high bactericidal activity against both test cultures of microorganisms. Already under the action of 1 pulse of the sterilizer MПК-300- 
3 registered inhibition of growth of $S$. aureus by $99.97 \%$ at a concentration of bacterial suspension of $1 \times 10^{6} \mathrm{CFU} / \mathrm{ml}, 99.65 \%-1 \times 10^{4} \mathrm{CFU} / \mathrm{ml}, 99.90 \%-$ $1 \times 10^{3} \mathrm{CFU} / \mathrm{ml}$. Under the influence of 2 and 5 pulses there is also a high efficiency of the device reaching $99.80-99.99 \%$, respectively. Under the influence of 10 pulses of the sterilizer, $100 \%$ death of S. aureus cells is detected in all studied concentrations of bacterial suspension. We also note that at an initial concentration of pathogens equal to $1 \times 10 \mathrm{CFU} / \mathrm{ml}$, the microbial residue after a single exposure was only $1 \mathrm{CFU}$, which is almost equivalent to the effect of monopulse sterilization.

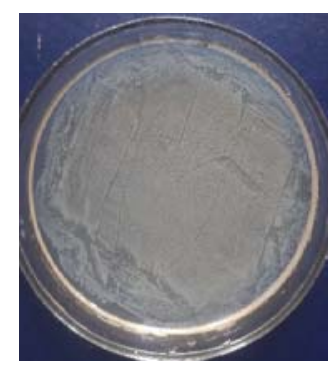

a)

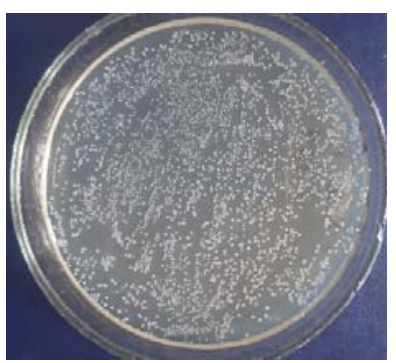

b)

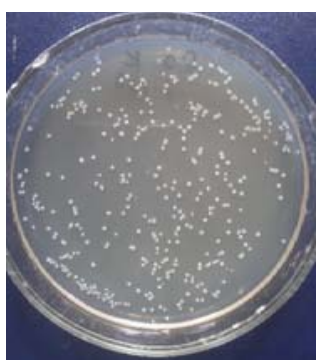

c)

Fig. 3. Initial inoculated cups with $S$. aureus $N_{0}=10^{6} \mathrm{CUO} / \mathrm{ml}(\mathrm{a}), N_{0}=10^{4} \mathrm{CUO} / \mathrm{ml}$ (b) and $N_{0}=10^{3} \mathrm{CUO} / \mathrm{ml}(\mathrm{c})$
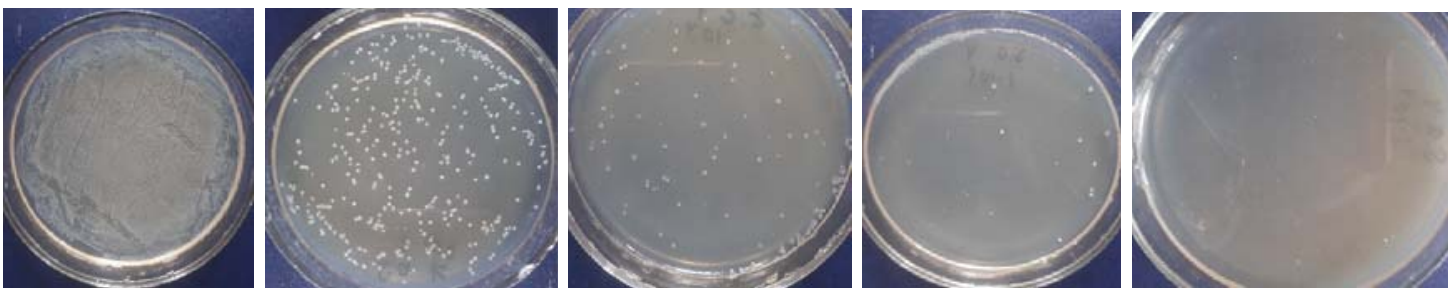

\begin{tabular}{|l|c|c|c|c|c|}
\hline $\begin{array}{l}\text { Control inoculated } \\
\text { cup }\end{array}$ & \multicolumn{6}{|c|}{ Tested cups resulted number of colonies $N_{\text {res }}$ after $n$ pulse exposures } \\
\hline \multirow{2}{*}{$10^{6} \mathrm{CFU} / \mathrm{ml}$} & $n$ & 1 & 2 & 5 & 10 \\
\cline { 2 - 6 } & $N_{\text {res }}$ & 272 & 124 & 16 & 0 \\
\hline
\end{tabular}

Fig. 4. Control and irradiated Petri cups inoculated with S.aureus and resulted number colonies dependence on pulse exposition

Inhibition of E. coli cell growth is also registered under the influence of 1 pulse of sterilizer MПK-300-3 by $99.95 \%$ at a concentration of bacterial suspension of $1 \times 10^{6} \mathrm{CFU} / \mathrm{ml}, 99.32 \%-1 \times 10^{4} \mathrm{CFU} / \mathrm{ml}, 99.00 \%-1 \times 10^{3}$ $\mathrm{CFU} / \mathrm{ml}$. Under the influence of 2 pulses, the efficiency of the device reaches $99.80-99.99 \%$. Under the action of 5 pulses of the sterilizer, $100 \%$ death of E. coli cells is detected in all studied concentrations of bacterial suspension (Tab. 2). Thus, E. coli bacteria are less resistant to pulsed UV radiation. 


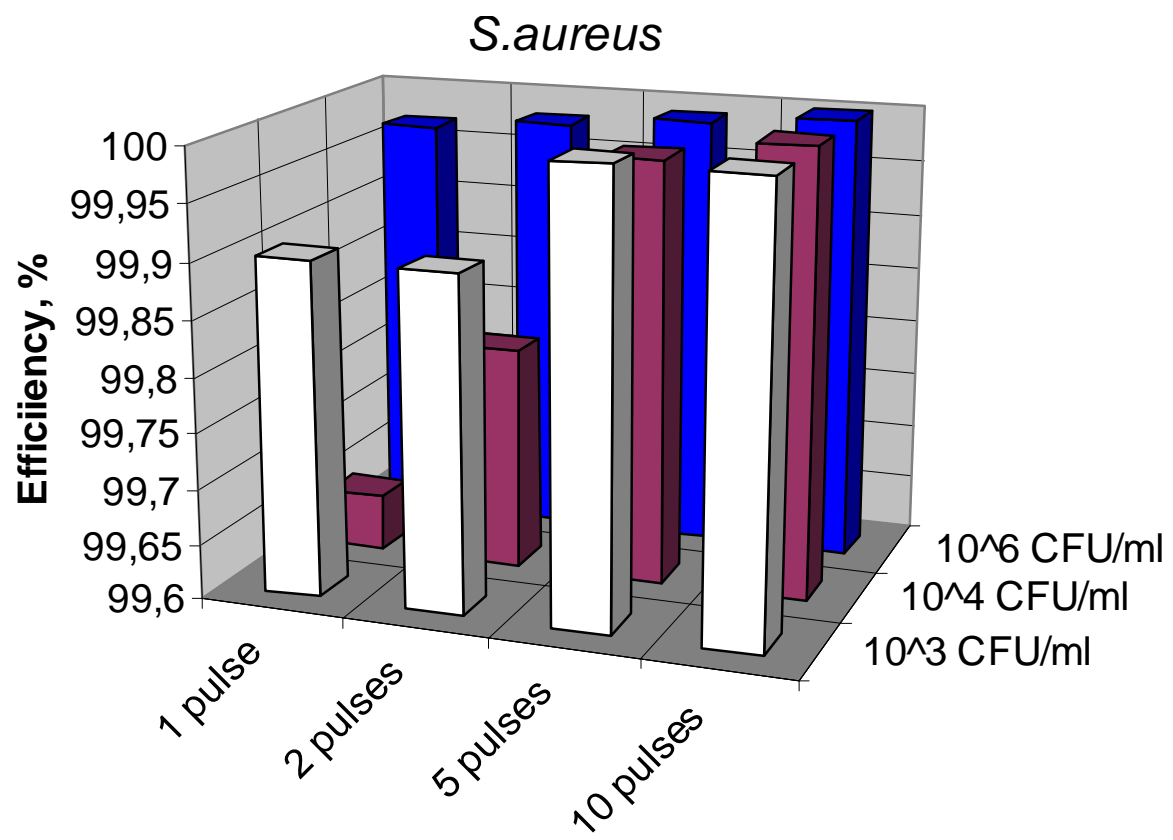

Fig.5. S. aureus sterilization efficiency dependence on number of pulse exposition

Therefore, based on the obtained data, it was found that the portable pulsed ultraviolet sterilizer MПK-300-3 has a high bactericidal effect on the studied opportunistic microorganisms $S$. aureus and $E$. coli with an efficiency of $100 \%$, and can be recommended for use to disinfect surfaces, products, premises of various function.

Table 2. The effectiveness of pulsed UV-radiation against $E$. coli

\begin{tabular}{|c|c|c|c|c|}
\hline Test-culture & $\begin{array}{l}\text { Initial bacterial } \\
\text { suspension } \\
\text { concentration, control, } \\
\text { CFU/ml }\end{array}$ & $\begin{array}{l}\text { Number of } \\
\text { pulse } \\
\text { exposition }\end{array}$ & $\begin{array}{l}\text { Resulted number of } \\
\text { growth colonies }\end{array}$ & $\begin{array}{l}\text { Efficiency } \\
\%\end{array}$ \\
\hline \multirow{12}{*}{ E. coli } & \multirow[t]{4}{*}{$10^{6}$} & 1 & 468 & 99,95 \\
\hline & & 2 & 71 & 99,99 \\
\hline & & 5 & 13 & 99,99 \\
\hline & & 10 & 0 & 100 \\
\hline & \multirow[t]{4}{*}{$10^{4}$} & 1 & 68 & 99,32 \\
\hline & & 2 & 7 & 99,93 \\
\hline & & 5 & 0 & 100 \\
\hline & & 10 & 0 & 100 \\
\hline & \multirow[t]{4}{*}{$10^{3}$} & 1 & 10 & 99,00 \\
\hline & & 2 & 2 & 99,80 \\
\hline & & 5 & 0 & 100 \\
\hline & & 10 & 0 & 100 \\
\hline
\end{tabular}




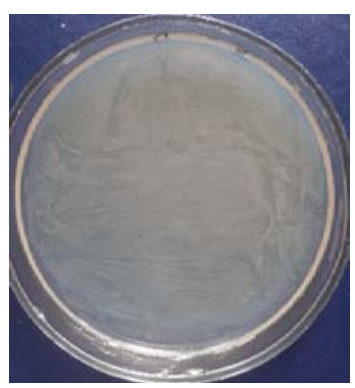

a)

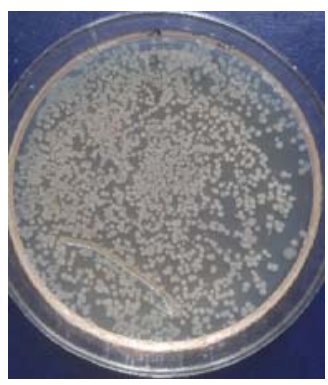

b)

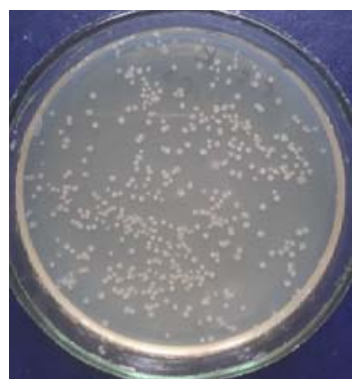

c)

Fig. 6. Initial inoculated cups with $E$. coli $N_{0}=10^{6} \mathrm{CUO} / \mathrm{ml}$ (a), $N_{0}=10^{4} \mathrm{CUO} / \mathrm{ml}$ (b) and $N_{0}=10^{3} \mathrm{CUO} / \mathrm{ml}$ (c)
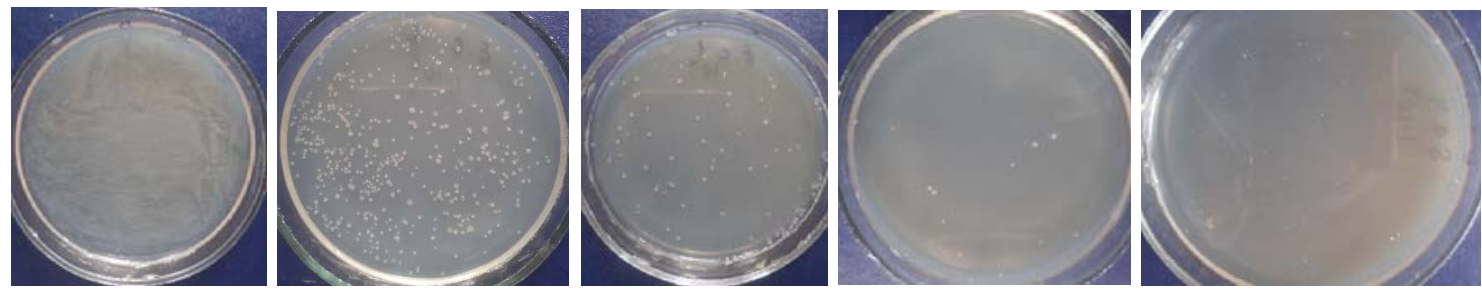

\begin{tabular}{|c|c|c|c|c|c|}
\hline Control inoculated & & cups & mbe & res a & posures \\
\hline $10^{6} \mathrm{CEI} / \mathrm{m}$ & $n$ & 1 & 2 & 5 & 10 \\
\hline & $N_{\text {res }}$ & 272 & 124 & 16 & 0 \\
\hline
\end{tabular}

Fig. 7. Control and irradiated Petri cups inoculated with E. coli and resulted number colonies dependence on pulse exposition

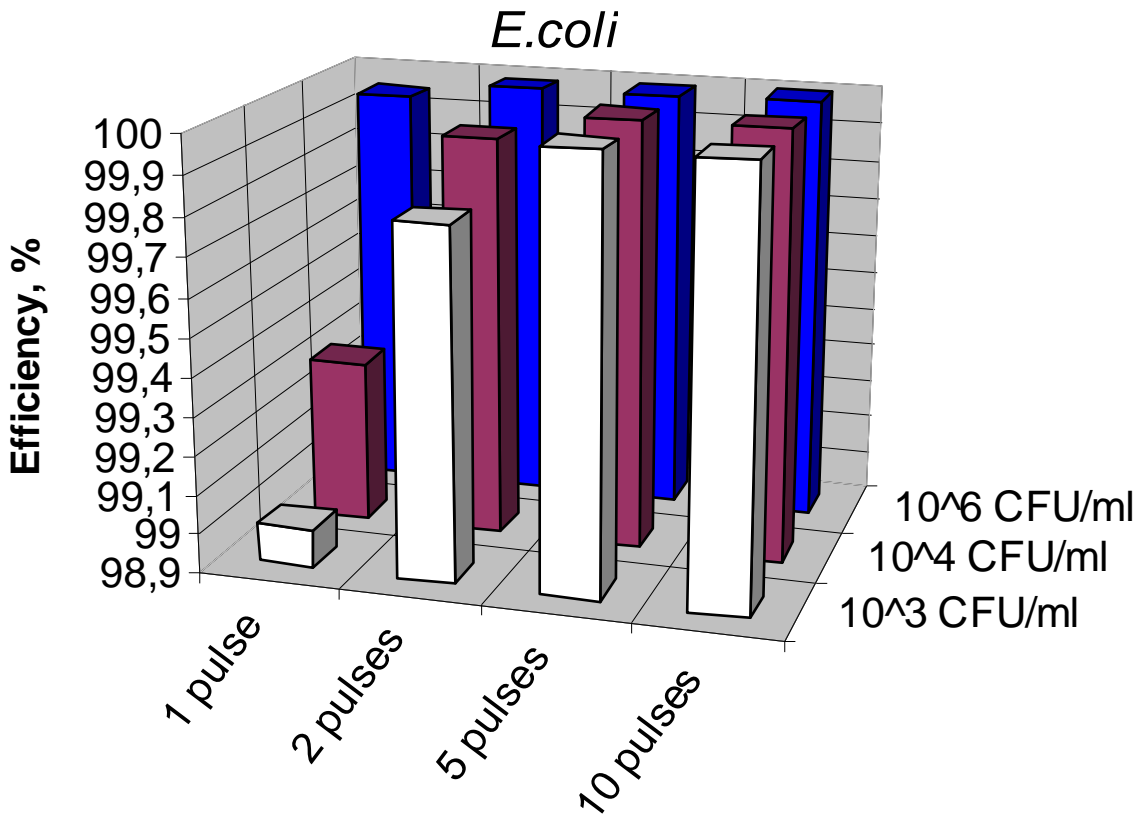

Fig.8. E.coli sterilization efficiency dependence on number of pulse exposition 


\section{CONCLUSIONS}

1. A pulsed source of high-power UV radiation has been developed and created for analyzing the bactericidal effect and determining the effectiveness of pulse sterilization.

2. The high bactericidal efficiency of high-power pulsed UV radiation when exposed to pathogens has been experimentally shown.

3. Exposure to pulsed UV radiation results in $100 \%$ complete sterilization as a result of irradiation with a finite number of pulsed exposures. Thus, the complete destruction of opportunistic pathogenic microorganisms S. aureus is achieved as a result of exposure to 10 pulsed exposures. The complete destruction of S. coli bacteria is achieved as a result of exposure to 5 pulses. A decrease in the initial concentration leads to a decrease in the pulsed radiation dose required for complete sterilization.

4. The results obtained determine the fundamental possibility of monopulse sterilization.

\section{References}

1. Shostko O.S., Shostko I.S., Lonin Yu.F., Chumakov V.I., Shostko S.N., Gorobets N.N., Dubrovskaya L.L. Bactericide Action of High-Power Pulsed Ultra-Violet Radiation // Telecommunication and Radioengineering, 1998, vol.52. N4, p.86-88. DOI:10.1615/TelecomRadEng.v52.i4.200

2. Chan-Ick Cheigh, Mi-Hyun Park, Myong-Soo Chung, Jung-Kue Shin, Young-Seo Park Comparison of intense pulsed light- and ultraviolet (UVC)-induced cell damage in Listeria monocytogenes and Escherichia coli O157:H7 // Food Control. 2012; 25: 654-659

3. Kelly Fitzhenry, Eoghan Clifford, Neil Rowan, Angeles Val del Rio Bacterial inactivation, photoreactivation and dark repair post flow-through pulsed UV disinfection // Journal of Water Process Engineering. 2021; 41: 102070

4. V. Heinrich,M. Zunabovic,T. Varzakas,J. Bergmair \&W. Kneifel Pulsed Light Treatment of Different Food Types with a Special Focus on Meat: A Critical Review //Critical Reviews in Food Science and Nutrition. 2016; 56 (4): 591-613

5. K. Rrishnamurthy, A. Demirci, J.M. Irudayaraj Inactivation of Staphylococcus aureus in Milk Using Flow-Through Pulsed UV-Light Treatment System //Food Microbiology and Safety. 2007; 72 (7)

6. Chumakov V, Ostryzhnyi M, Kharchenko O, Naumenko K, Zagorodnya S, Muraveinyk V, et al. Pulse UV Sterilization of Viral Infection Enliven: Microb Microbial Tech. 2021; 8(2): 001. http://www.enlivenarchive.org/articles/pulse-uv-sterilization-of-viralinfection.pdf]

7. Ukrainian collection of microorganisms. Catalog of Cultures / Ed. V.S. Podgorskiy, O.I. Konofliak, E.A. Kiprianova, O.R. Gvozdiak. - Kiev: Naukova dumka, 2007.-270 p.

8. State Pharmacopoeia of Ukraine. 1 edition. State Enterprise "Scientific and Expert Pharmacopoeial Center". - Kharkiv: RIREK. - 2001.-556 p. 